\title{
Effect of Service Quality and Company Image on Customer Loyalty with Satisfaction Customers as Intervening Variables (Case Study of Brilink Agent PT Bank Rakyat Indonesia (Persero) TBK. Medan Region Office)
}

\author{
Apri Hendrawan ${ }^{1}$, Amrin Fauzi ${ }^{2}$, Beby Karina Fawzeea ${ }^{3}$ \\ ${ }^{1,2,3}$ Department of Management, University of Sumatera Utara, Medan, Indonesia.
}

Corresponding Author: Apri Hendrawan

\begin{abstract}
Bank is a business entity that collects funds from the public such as deposits and it will be distributed to the public in the form of credit and I or other forms in order to improve people's lives. The objective of Indonesian banking is to support the implementation of national development in the context of increasing equity, economic growth and national stability towards improving people's welfare. From this objective, banks in Indonesia must carry out their duties and functions properly and be based on the principles of economic democracy. The Brilink agent is one of BRI's breakthroughs to educate people in knowing basic knowledge about financial management by use banking's products and services. BRI provides financial services through Brilinkagentat remote villages. BRILink agent give service not only provides operational efficiency benefits, but also provides convenience for BRI's customers and non customers when they making transaction with BRI. Phenomena that often occur in BRI Bank customers against Brilink Agents, both directly and indirectly, such as the quality of service provided to customers that are not up to standard so that it can lead to the customer's decision to return to transactions at Brilink Agents and the impact of these problems will decrease the number of transactions and decreased fee-based income for Brilink agents. The purpose of this study was analyzed the effect of service quality and corporate image on customer loyalty through satisfaction as an
\end{abstract}

intervening variable at the Brilink agent of PT Bank Rakyat Indonesia (Persero) Tbk Medan regional office. The population of this research is customers in the micro segment. Sample criteria are customers who have transaction at Brilink agents, a total sample are 400 respondents. The sampling method used Purposive Sampling. Data analysis was carried out through PLS-SEM using the SmartPLS 3.0 program. The results showed that directly service quality and company image had a positive and significant effect on customer loyalty through customer satisfaction.

Keywords: Service Quality, Company Image, Customer Satisfaction, Customer Loyalty

\section{INTRODUCTION}

Economic growth and equity are indicators in the development process of a country, especially for developing countries where development is directed at achieving a level of prosperity for its people. Basically every banking company will grow and develop both the external environment and the internal environment. The survival of each company does not only depend on its ability to generate profits by maximizing the performance of financial services. There are other factors that also influence and determine the company's ability to profit from its activities. These other factors are called the business environment or business climate. 
Apri Hendrawan et.al. Effect of service quality and company image on customer loyalty with satisfaction customers as intervening variables (case study of Brilink Agent PT Bank Rakyat Indonesia (Persero) TBK. Medan Region Office).

At the end of 2019, a corona outbreak emerged that had shaken all business sectors in the world. The Covid-19 pandemic has also affected the weakening of the banking sector in Indonesia. In this Covid-19 pandemic, the company lost focus in carrying out its strategy due to problems in cost management or starting to lose confidence in its differentiation. Companies that still have the highest cost efficiency or companies that have unique differentiation will have an advantage in competing against this pandemic.

PT Bank Rakyat Indonesia (Persero) Tbk through its Brilink agent seeks to encourage financial inclusion for the community. The number of BRILink agents throughout Indonesia at the end of December 2020 was 504,233 agents or grew from the position at the end of December 2019 of 82,073 agents. Until April 2021 the number of Brilink agents throughout Indonesia was 452,305 agents, the growth of brilink agents has increased every year and the highest increase was in 2017. The increase in the number of agents in 2017 has increased due to new media, namely through mobile devices called Brimob (Brilink Mobile). .

Each Brilink Agent can serve all customers, both BRI customers and other bank customers. With this service, customers in the deepest areas can be helped in making transactions. Currently, BRILink agents can serve various transactions needed by the community. These transactions include transfers, cash withdrawals, deposit payments for PLN electricity bills, water, BPJS contributions, telephone calls, credit purchases, installment payments, BRIZZI top-ups, Gopay, OVO, and various other transactions. In addition, AgenBRILink also provides referral services for opening savings and loan accounts.

In the banking industry, customer loyalty is one of the most important factors in business survival and the development of a competitive environment (Bilika et al., 2016). Basically, customer loyalty is needed by companies to improve service quality, especially service companies. Loyal customers will tend to use the services of the bank, and will not choose other banks, do not try new products from competing banks, and encourage others to become customers (Suwono and Sihombing, 2016). Now many banks have realized the value of current customers and are trying to find ways to increase customer loyalty (Taghipourian and Bakhsh 2016). This is the main consideration for customers before coming to the bank to purchase products or use their services. Service quality and customer satisfaction are very important for banks to build customer loyalty. In service companies, especially in the banking sector, service quality has a very important role, therefore with the good quality of services provided by Brilink Agents, it is hoped that consumers will be satisfied with the services offered and will become loyal customers. Corporate image is one of the most important things in terms of the influence of customer loyalty to the company where they have a reciprocal relationship, a phenomenon that often occurs in BRI Bank customers to Brilink Agents either directly or indirectly, such as the quality of services provided to customers that are not up to standard. so that it can lead to the customer's decision to return to transactions at Brilink Agents. Basically Brilink Agents have never had any socialization or education from BRI regarding services to customers, so there are still many agents who still do not understand the importance of service quality. If the customer gets good service, the customer will feel satisfied and will be loyal to Brilink and BRI agents. According to previous research conducted by $\mathrm{Al}$ Amin and Ahmad Yunadi (2016) which stated that company image had no significant effect on customer loyalty, while according to research conducted by Chusnul Rofiah and Dwi Wahyuni (2017), found research results stating that the test results are proven that the quality of service has a significant effect on customer loyalty and research conducted by Putri Apriyanti, Djasuro Surya, Lutfi (2017) found research results stating that 
Apri Hendrawan et.al. Effect of service quality and company image on customer loyalty with satisfaction customers as intervening variables (case study of Brilink Agent PT Bank Rakyat Indonesia (Persero) TBK. Medan Region Office).

company image has a significant effect on customer loyalty

\section{LITERATURE REVIEW \\ Service quality}

Tjiptono (2019) stated that "quality is a dynamic condition related to products, services, people, processes and the environment that meet or exceed expectations". Meanwhile, according to Kotler and Keller (2016), service quality is the overall characteristics of a product or service that affect its ability to meet stated or unstated needs and desires of clients. And according to other experts such as Rusydi (2017) service quality is the expected level of excellence and control over the level of excellence to meet consumers. Service quality in this sense explains that what is upheld by consumers is judged by how the company provides the best service to its customers, because with this service a consumer can assess and provide a satisfaction to survive or look for better. According to Tjiptono (2016), there are five dominant factors determining service quality, namely Tangible, Empathy, Reliability, Responsiveness, Assurance.

\section{Company Image}

Image is the impression that a person feels about an object or item or the organization as a whole which will then be stored in the consumer's memory (Kotler \& Keller, 2016). Corporate image has several important objects, namely the impression of the object, the process of image formation, and reliable sources. Objects include companies, individuals, and people who are in them. Corporate image is one part that is considered important by companies, both large-scale companies and small-scale companies (Yustriany, 2017). Corporate image is an impression in a person's mind that comes from a collection of feelings, attitudes, ideas, and experiences about the company. These impressions can be positive or negative according to experience. Customers will recall that impression when they hear the name of the company
(Suratno, et al, 2016). Meanwhile, according to Kotler and Keller (2013) corporate image can be measured by looking at: personality, reputation, values, corporate identity.

\section{Customer Satisfaction}

Customer satisfaction is the feeling of pleasure felt by people or legal entities that have accounts in banking that appears after comparing the expected results. To increase customer satisfaction, Brilink Agents have no other choice but to professionally improve human resources, as the main capital of services to customers. , and strives to continuously perform various efficiency and service differentiations that can increase output. For this reason, PT Bank Rakyat Indonesia (Persero) Tbk is required to continue to recognize and respond to various external factors that need to be considered in an effort to improve the quality of Brilink Agents.

\section{Customer Loyalty}

According to Kotler and Keller (2016) the definition of customer loyalty is a deeply held commitment to rebuy or repatronize a preferred a product or service in the future despite situational influences and marketing efforts having the potential to cause switching behavior. This definition is in line with the definition of customer loyalty put forward by $\mathrm{Yi}$ in the journal Iddrisu, Nooni, Fianko and Mensah (2015), which is as follows: "Customer loyalty can be defined in two different ways. First, loyalty is attitude. Different feelings create an individual's overall attachment to a product, service, or organization. These feelings define the individual's (purely cognitive) degree of loyalty. The second definition of loyalty is behavioral. Examples of loyalty behavior include continuing to purchase services from the same supplier, increasing the scale and or scope of relationship, or the act of recommendation. Customer loyalty is an important thing that must be maintained by the company for the sustainability of the company and can 
Apri Hendrawan et.al. Effect of service quality and company image on customer loyalty with satisfaction customers as intervening variables (case study of Brilink Agent PT Bank Rakyat Indonesia (Persero) TBK. Medan Region Office).

improve good relationships between service providers and their customers. Loyal customers will benefit the company because loyal customers can indirectly contribute to the services they have felt for their family or colleagues. Loyal customers will always use the services of the company and are reluctant to use the services of other banks.

\section{MATERIALS \& METHODS}

The type of research used by the author is associative research with a quantitative approach. According to Sugiyono (2018), associative research is research that aims to determine the effect or relationship between the independent variable (independent variable) and the dependent variable (dependent variable) and how closely the relationship is between the two. The place of this research was conducted at PT Bank Rakyat Indonesia (Persero) Tbk Medan Regional Office located at Uniland Building JL. Let. Gen. M.T. Haryono, No. A-1, Medan City, North Sumatra, 20231. The population in this study is all customers of PT Bank Rakyat Indonesia (Persero) Tbk in the BRI Regional Office of Medan, both Loan customers (debtors) and Micro segment customers who transact at BRI Brilink Agent. The number of micro segment debtors in April 2021 was 551,249 debtors and 6,746,192 micro segment savings customers. The technique or sampling used in this research is purposive sampling. Determination of the sample size in this study was carried out using the Slovin formula and certain criteria, namely the customers of PT Bank Rakyat Indonesia (Persero) Tbk in the Micro segment at the Medan Regional Office with the following calculations:

Slovin's formula:

$$
n=\frac{N}{1+N(e)^{2}}
$$

By using the above formula, the number of research samples can be calculated as follows:

$$
\begin{aligned}
& n=\frac{7.297 .441}{1+7.297 .441(0.05)^{2}} \\
& n=399.98 \text { rounded up to } 400 \text { Customers. }
\end{aligned}
$$

\section{RESULT}

\section{Respondent's Descriptive}

Based on the results of the analysis of the characteristics of the respondents, it is known that respondents aged 46-55 years are more dominant in transacting at brilink agents because that age is included in the productive age for entrepreneurs and office workers. dominant compared to female respondents, while the characteristics of respondents based on domicile area are known that the majority are customers of the Medan Iskandar Branch working area young. Characteristics of respondents based on strata, it is known that brilink agent customers with $\mathrm{S} 1$ strata make more transactions at brilink agents, then based on occupation, it is known that self-employed respondents are more dominant than other occupations. As for the frequency of visits, it is known that respondents visit less than 5 times a month. The activity of the visit is to withdraw deposits.

\begin{tabular}{|c|c|c|c|c|c|}
\hline \multicolumn{6}{|l|}{ Direct Effect } \\
\hline & $\begin{array}{l}\text { Original } \\
\text { Sample }(0)\end{array}$ & $\begin{array}{l}\text { Sample } \\
\text { Mean(M) }\end{array}$ & $\begin{array}{l}\text { Standard } \\
\text { Deviation(STDEV) }\end{array}$ & $\begin{array}{l}\text { Tr Statistics } \\
(\mid \text { O/STDEV })\end{array}$ & $\begin{array}{l}\mathbf{P} \\
\text { Values }\end{array}$ \\
\hline Company Image -> Customer Loyalty & 0,143 & 0,139 & 0,042 & 3,385 & 0,000 \\
\hline Company Image -> Customer Satisfaction & 0,327 & 0,322 & 0,073 & 4,489 & 0,000 \\
\hline Service Quality -> Customer Loyalty & 0,368 & 0,380 & 0,081 & 4,544 & 0,000 \\
\hline Customer Satisfaction -> Customer Loyalty & 0,480 & 0,470 & 0,072 & 6,691 & 0,000 \\
\hline Service Quality -> Customer Satisfaction & 0,507 & 0,514 & 0,073 & 6,912 & 0,000 \\
\hline \multicolumn{6}{|l|}{ Indirect Effect } \\
\hline $\begin{array}{l}\text { Company Image -> Customer Satisfaction }->\text { Customer } \\
\text { Loyalty }\end{array}$ & 0,157 & 0,154 & 0,049 & 3,182 & 0,002 \\
\hline $\begin{array}{llllll}\text { Kualitas } & \text { Layanan } & \text {-> } & \text { Customer } & \text { Satisfaction } & \text {-> } \\
\text { Customer Loyalty } & & & \end{array}$ & 0,244 & 0,239 & 0,037 & 6,595 & 0,000 \\
\hline
\end{tabular}

\section{Data Analysis}

Table 1: Test Results of Direct and Indirect Effects 
Apri Hendrawan et.al. Effect of service quality and company image on customer loyalty with satisfaction customers as intervening variables (case study of Brilink Agent PT Bank Rakyat Indonesia (Persero) TBK. Medan Region Office). directly:

Based on Table 1, it is known that

1. Company image has a positive and significant effect on customer loyalty

2. Company image has a positive and significant impact on customer satisfaction

3. Service quality has a positive and significant impact on customer loyalty

4. Customer satisfaction has a positive and significant effect on customer loyalty

5. Service quality has a positive and significant impact on customer satisfaction

While indirectly it is known that:

1. Company image has a positive and significant impact on customer loyalty through customer satisfaction

2. Service quality has a positive and significant impact on customer loyalty through customer satisfaction

\section{DISCUSSION}

\section{The Influence of Service Quality on Customer Satisfaction}

Based on the results of hypothesis testing, it shows that the service quality variable has a positive and significant effect on customer satisfaction. This is evidenced by the significance value for service quality of 0.000 with an alpha of $5 \%$, namely ( $\mathrm{p}=$ $0.000<0.05$ ), meaning that service quality has a significant effect on customer satisfaction. Meanwhile, according to several studies by Komang et al (2016); Alfi Syahri Lubis et al (2017) and Frizky Yuniarta et al (2019), state that service quality has a positive and significant influence on satisfaction.

\section{The Influence of Company Image on Customer Satisfaction}

Based on the results of hypothesis testing, it shows that the corporate image variable has a positive and significant effect on customer satisfaction. This is evidenced by the significance value for the corporate image variable 0.000 with an alpha of $5 \%$, namely $(\mathrm{p}=0.000<0.05)$, meaning that the company's image has a significant effect on customer satisfaction. This research is in line with research conducted by Luh Ayu Mulyaningsih et al (2016) and Mutmainah (2017), which states that company image has a positive and significant influence on satisfaction.

\section{The Influence of Service Quality on Customer Loyalty}

Based on the results of hypothesis testing, it shows that the service variable has a positive and significant effect on customer loyalty. This is evidenced by the significance value for the service quality variable of 0.000 with an alpha of $5 \%$, namely $(\mathrm{p}=0.000<0.05)$, meaning that service quality has a significant effect on customer loyalty. This research is in line with research conducted by Mutmainnah (2017), Amrin Fauzi at al (2019), Indah Gita Cahyani at al (2016) which states that service quality has a positive and significant effect on customer loyalty.

\section{The Influence of Corporate Image on Customer Loyalty}

Based on the results of hypothesis testing, it shows that the corporate image variable has a positive and significant effect on customer loyalty. This is evidenced by the significance value for the Service Quality variable of 0.000 with an alpha of $5 \%$, namely $(\mathrm{p}=0.000<0.05)$, meaning that the company's image has a significant effect on customer loyalty. This research is in line with research conducted by Mutmainnah (2017) and I Gusti Agung et al (2016), showing that company image has a positive and significant effect on customer loyalty. With the better the company's image, it will be an aspect in determining customer loyalty.

\section{The Influence of Customer Satisfaction on Customer Loyalty}

Based on the results of hypothesis testing, it shows that the customer satisfaction variable has a positive and significant effect on customer loyalty. This is evidenced by the significance value for 
Apri Hendrawan et.al. Effect of service quality and company image on customer loyalty with satisfaction customers as intervening variables (case study of Brilink Agent PT Bank Rakyat Indonesia (Persero) TBK. Medan Region Office).

the customer satisfaction variable of 0.000 with an alpha of $5 \%$, namely $(\mathrm{p}=0.000$ $<0.05$ ), meaning that customer satisfaction has a significant effect on customer loyalty. This research is in line with research conducted by Arif Rakhman1 et al (2013), Karin Boonlertvanich (2019), Frizky Yuniarta et al (2019) which states that customer satisfaction has a positive effect on customer loyalty.

\section{Influence of Service Quality on Customer Loyalty through Customer Satisfaction}

Based on the hypothesis test, it is known that Service Quality has a positive and significant effect on the customer loyalty variable through customer satisfaction. This is evidenced by the significance value of 0.000 with an alpha of $5 \%(\mathrm{p}=0.000<0.05)$, meaning that service quality has a significant effect on customer loyalty through customer satisfaction. This research is in line with research conducted by Pınar zkan et al (2019), Charles Makanyeza (2017), Adji Achmad Rinaldo Fernandes et al (2017) which shows that service quality has a positive and significant effect on customer loyalty through customer satisfaction.

\section{Influence of Corporate Image on Customer Loyalty through Customer Satisfaction}

Based on the hypothesis test, it is known that the company's image has a positive and significant effect on the customer loyalty variable through customer satisfaction. This is evidenced by the significance value of 0.000 with an alpha of $5 \%(\mathrm{p}=0.000<0.05)$, meaning that the company's image has a significant effect on customer loyalty through customer satisfaction. According to several studies such as Afwan (2018), Netty and Siska (2018), Karyose et al (2017) and El-Salam and Shawky (2013) show that company image has a positive and significant effect on customer loyalty through customer satisfaction.

\section{CONCLUSION}

1. Service Quality has a positive and significant effect on Customer Satisfaction at the Brilink Agent of PT Bank Rakyat Indonesia (Persero) Tbk.

2. Company image has a positive and significant effect on Customer Satisfaction at the Brilink Agent of PT Bank Rakyat Indonesia (Persero) Tbk.

3. Service Quality has a positive and significant impact on Customer Loyalty at Brilink Agent PT Bank Rakyat Indonesia (Persero) Tbk.

4. Company image has a positive and significant effect on Customer Loyalty at Brilink Agent PT Bank Rakyat Indonesia (Persero) Tbk.

5. Satisfaction has a positive and significant effect on customer loyalty at the Brilink Agent of PT Bank Rakyat Indonesia (Persero) Tbk.

6. Service quality has a positive and significant impact on customer loyalty through customer satisfaction at Brilink Agent PT Bank Rakyat Indonesia (Persero) Tbk.

7. Corporate image has a positive and significant effect on customer loyalty through customer satisfaction at Brilink Agent PT Bank Rakyat Indonesia (Persero) Tbk.

Acknowledgement: None

Conflict of Interest: None

\section{Source of Funding: None}

\section{REFERENCES}

1. Al Amin dan Ahmad Yunadi, 2016, “ Analisa pengaruh usia perusahaan total asset dan citra perusahaan terhadap loyalitas nasabah studi kasus di BMT beringharjo Yogyakarta" Jurnal ekonomi syariah Indonesia, Volume VI, No $1: 1-11$.

2. Alfi Syahri Lubis, Nur Rahmah Andayani ,2017." Pengaruh Kualitas Pelayanan (Service Quality) Terhadap Kepuasan Pelanggan PT Sucofindo Batam", Journal of Business Administration Vol 1, No 2, hlm. \&\#13;232-243 
Apri Hendrawan et.al. Effect of service quality and company image on customer loyalty with satisfaction customers as intervening variables (case study of Brilink Agent PT Bank Rakyat Indonesia (Persero) TBK. Medan Region Office).

3. Bilika, F., Safari, M., Mansori, S., 2016. "Service Quality and Customer Satisfaction in Mozambique Banking System" . Journal of management and Customer Behavior. Vol 1.

4. Charles Makanyeza, 2017. "Mediators of the relationship between service quality and customer loyalty Evidence from the banking sector in Zimbabwe", International Journal of Bank Marketing Vol. 35 No. 3, 2017 pp. 540-556 @ Emerald Publishing Limited

5. Chusnul Rofiah1, Dwi Wahyuni, 2017. Kualitas Pelayanan Dan Pengaruhnya Terhadap Loyalitas Pelanggan Yang Di Mediasi Oleh Kepuasan Di Bank Muamalat Jombang, Jombang.

6. Frizky Yuniarta, Ika Barokah S, Gusti Ayu Wulandari, 2019." Pengaruh Kepercayaan dan Kualitas Pelayanan Terhadap Loyalitas Pelanggan Pengguna Jasa Pengiriman Paket Pada PT JNE Express Cabang Jember dengan Kepuasan Sebagai Variabel Intervening". e-Journal Ekonomi Bisnis dan Akuntansi, Volume VI (1) : 152-158.

7. Iddrisu, A., M., I. K. Nooni, Fianko, K. S., and W.Mensah, 2015, Assessing the Impact of Service Quality on Customer Loyalty: "A Case Study of the cellular Industry of Ghana",British Journal Of Marketing Studies, Vol.3 No.6.

8. Karin Boonlertvanich,2019. "Service quality, satisfaction, trust, and loyalty: the moderating role of main-bank and wealth status", International Journal of Bank Marketing Vol. 37 No. 1, pp. 278-302 () Emerald Publishing Limited

9. Kotler, Philip dan Kevin L.Keller, 2013. "Marketing Manajemen", $14^{\text {th }}$ Edision. Global Edition. Pearson Pretince Hall.

10. Kotler, Philip and Kevin Lane Keller,2016. "Marketing Management" $15^{\text {th }}$ Edition, Pearson Education,Inc.

11. Luh Ayu Mulyaningsih, I Gst Agung Ketut Gede Suasana, 2016, "Pengaruh kualitas layanan dan citra perusahaan terhadap kepuasan nasabah pada Bank OCBC NISP di Denpasar", E-Jurnal Manajemen Unud, Vol. 5, No. 1, 2016: 1-30
12. Mutmainnah (2017), "Pengaruh Kualitas layanan dan citra perusahaan terhadap kepuasan dan loyalitas nasabah", Jurnal Manajemen dan Pemasaran Jasa Vol. 10 No. 2 September 2017: 201-216

13. Pınar Özkan, Seda Süer, 2020. "The effect of service quality and customer satisfaction on customer loyalty", International Journal of Bank Marketing Vol. 38 No. 2, pp. 384405 @ Emerald Publishing Limited.

14. Putri Apriyanti, Djasuro Surya, Lutfi, 2017, "Analisa kualitas layanan citra perusahaan terhadap loyalitas nasabah dengan kepuasan nasabah sebagai variabel intervening (studi empiric nasabah tabungan tandamata Bank BJB cabang serang)" Jurnal Riset Bisnis dan Manajemen Tirtayasa (JRBMT), Vol. 1 (2): hh. $159-166$

15. Rusydi. Mhd.2017. "Customer Excelence, Yogyakarta

16. Sugiyono. 2018. "Metode Metode Penelitian kombinasi (Mix Methods)". Bandung : Alfabeta.

17. Suratno, 2016. "Pengaruh citra perusahaan dan kualitas pelayanan terhadap loyalitas pelanggan dengan kepuasan sebagai variabel intervening pada PT Pelabuhan Indonesia 111 Semarang". Journal of Management, Volume 2, No.2.

18. Suwono, L.V., Sihombing, S.O., 2016 Factors Affecting Customer Loyalty of Fitness Centers : An Emirical study, Jurnal DInamika Manajemen.Vol. 7,45-55.

19. Tjiptono, 2019.’Pemasaran Jasa", Edisi terbaru. Yogyakarta : Andi Offset.

20. Taghipourian, M.J, Bakhsh, M.M, 2016. Brand Attachment on Service Loyalty in Banking Sector. International journal marketing studies. Vol. 8,146.

How to cite this article: Hendrawan A, Fauzi A, Fawzeea BK. Effect of service quality and company image on customer loyalty with satisfaction customers as intervening variables (case study of Brilink Agent PT Bank Rakyat Indonesia (Persero) TBK. Medan Region Office). International Journal of Research and Review. 2021; 8(8): 196-202. DOI: https://doi. org/10.52403/ijrr.20210827 